\title{
A representação do negro em Cogumelos de Outono (1972) de Gladstone Osório Mársico
}

\author{
The representation of the black man in Autumn Mushrooms (1972) by Gladstone Osório \\ Mársico
}

Resumo: O artigo analisa a representação do negro na literatura pós-moderna, especificamente no romance, Cogumelos de Outono do escritor erechinense Gladstone Osório Mársico (1927-1976). O recorte do estudo é o ano de publicação da obra, em 1972, e a ambientação proposta pelo autor - mesmo quando faz uso de cidades fictícias - é Erechim, localizada no norte do Rio Grande do Sul. Erechim ex-distrito de Passo Fundo, foi emancipada em 30 de abril de 1918. Trata-se de uma região povoada por indígenas, caboclos, lusos, afrodescendentes e, posteriormente, por outros imigrantes. Neste ambiente o escritor e vereador erechinense se inspirou para elaboração de sua obra satírica ficcional. $\mathrm{O}$ estudo, em termos teóricos metodológicos, dialoga com a História Cultural e situa-se na fronteira entre a Literatura e a História. O cruzamento de fontes inclui revisão bibliográfica e utiliza para a análise o conceito de representações de Roger Chartier.

Palavras-chave: Representações; Negro; Cogumelos de Outono; Gladstone Osório Mársico.

\author{
Gláucia Elisa Zinani Rodrigues \\ Doutoranda em História \\ UPF - Universidade de Passo Fundo \\ Bolsista FUPF \\ glaucia.zinani@gmail.com
}

Abstract: The article analyzes the representation of the black in postmodern literature, specifically without a novel, Mushrooms of Autumn by the Erechinese writer Gladstone Osório Mársico (1927-1976). The focus of the study is the year of publication of the work, in 1972, and the setting proposed by the author - even when making use of fictional cities - is Erechim, located in the north of Rio Grande do Sul. Erechim ex-district of Passo Fundo, it was emancipated on April 30, 1918. It is a region populated by indigenous people, caboclos, lusos, afro-descendants and, later, by other immigrants. In this environment, the Erechinese writer and councilor was inspired to elaborate his fictional satirical work. The study, in theoretical methodological terms, dialogues with Cultural History and stands on the border between Literature and History. Cross-checking includes bibliographic review and use for an analysis of the concept of representations by Roger Chartier.

Keywords: Representations. Black. Autumn mushrooms. Gladstone Osório Mársico. 


\section{Introdução}

O escritor Gladstone Osório Mársico nasceu em 1927 em Erechim/ RS, e faleceu em 1976 em Porto Alegre. Formado em Direito, atuou como advogado da companhia de imigração judaica, Jewish Colonization Association ${ }^{1}$ (ICA), e ocupou o cargo de vereador municipal no período de 1956-1959. Mársico escreveu inúmeros artigos para o jornal $A$ Voz da Serra, para revistas locais e fez discursos em rádio. Dirigiu o clube esportivo Ipiranga Futebol Clube ${ }^{2}$ no período de 1970-1971, administrando a construção de seu estádio de futebol. Sua atuação junto à comunidade foi expressiva nessas e outras atividades. Além dessa participação, há que se destacar que mesmo usando nomes fictícios para as cidades que constam em suas publicações, é Erechim que serve de lócus e inspiração ao autor.

Na literatura, Mársico dedicou sua breve carreira nas letras às obras marcadas pelo uso do humor e o pitoresco ${ }^{3}$ da sociedade moderna, produzindo um livro de contos e quatro romances satíricos. Produziu o livro de contos: Minha Morte e Outras Vidas (1958), e quatro romances: Gatos à Paisana (1962) Cogumelos de Outono (1972) Cágada (ou a história de um município a passo de) (1974) e Furúnculo (1994) póstumo, através da pesquisa de Vera Beatriz Sass. Segundo Soethe (1998: 7):

O termo sátira remete, em primeiro lugar, a um gênero histórico, definido já a partir da tradição clássica (com desdobramentos até a era moderna) - seja pela vertente lucílica (também denominada romana), seja pela vertente menipéia (ou luciânica). Em rápidas palavras, a sátira de tradição lucílica caracteriza-se pela utilização regular de hexâmetros e pela finalidade moralizadora dos textos; nela o riso é utilizado como meio de denúncia dos vícios da humanidade. Os romanos a consideravam uma invenção sua. O riso é sua marca distintiva, sem assumir, no entanto, o caráter exclusivamente moralista

\footnotetext{
${ }^{1}$ Companhia judaica de imigração, criada em 11 de setembro de 1891 por Moritz Hirsch. Seu propósito foi facilitar a emigração em massa de judeus da Rússia e outros países do Leste Europeu, assentando-os em colônias agrícolas em terras por ela adquiridas, particularmente na América do Norte e América do Sul, em especial na Argentina e no Brasil.

2 O Ipiranga Futebol Clube, é um clube de futebol brasileiro com sede na cidade de Erechim, no estado do Rio Grande do Sul, tem sua fundação datada de 18 de agosto de 1924.

${ }^{3}$ Poder-se-á ler no Lazarilho, apenas uma série de histórias engraçadas; mas também poder-se-á pensar que a obra é portadora de uma denúncia não explícita, segundo González (1988: 10).
} 
da tradição romana.

Para este artigo optou-se em analisar Cogumelos de Outono ${ }^{4}$, obra publicada em 1972, pela Editora Movimento. Para este artigo, objetiva-se analisar as representações sobre os negros na obra. Em sua literatura satírico-marginal Mársico não satiriza somente as personagens afrodescendentes, mas todas as representações multiétnicas, todavia para este trabalho restringimos nosso foco a este grupo étnico cultural.

Teoricamente, o estudo está situado na fronteira entre a História e a Literatura. Sandra Pesavento (2003: 80) define, que “[...] a relação entre a História e a Literatura se resolve no plano epistemológico, mediante aproximações e distanciamentos, entendendoas como diferentes formas de dizer o mundo, que guardam distintas aproximações com o real".

Segundo Chartier (1998), o livro é uma produção cultural e a leitura é a prática criadora do leitor, recriada de acordo com sua competência textual. No ato da leitura de obras literárias, o leitor, para compreender o texto, precisa decodificar o texto e significar as diferentes representações presentes, a fim de reconhecer uma identidade social. $\mathrm{O}$ artigo utiliza o conceito de representação do historiador francês, Roger Chartier (1988: 20), que a define como sendo um: "[...] instrumento de um conhecimento mediato que faz ver um objeto ausente através da sua substituição por uma <imagem> capaz de o reconstituir em memória e o de figurar tal como ele é".

Em Cogumelos de Outono, a trama imaginária se inicia por volta de 1923 e se estende até 1945, na cidade fictícia de Boa Vista, localizada no Vale do Rio Dourado. A trama conta com a participação das personagens afrodescendentes que atuam da narrativa, como o coveiro Maroca e o tropeiro Maroca dos Prazeres. Através deste artigo será possível analisar a representação afrodescendente destas duas personagens.

\section{A representação do negro em Cogumelos de Outono}

O início da formação étnica sul rio-grandense, mais especificamente a região do Alto Uruguai, que inclui Erechim RS, ex-distrito de Passo Fundo. Há séculos a região

\footnotetext{
${ }^{4}$ O crítico literário Temístocles Linhares, em sua obra História Crítica do Romance Brasileiro (1987: s/p), considerou Cogumelos de Outono "o maior romance satírico jamais escrito entre nós".
} 
habitada por índios Caingangues ${ }^{5}$, famílias designadas de Birivas $^{6}$ e, posteriormente, povoada por posseiros de origem lusa que vinham para o estado buscar o gado para revendê-lo em São Paulo. A região também foi povoada por fugitivos das Revoluções Farroupilha $^{7}$ e Federalista $^{8}$, e por caboclos ${ }^{9}$ seminômades que viviam sobretudo da exploração da erva-mate nativa, conforme Baldiserra (2008).

Garcez (2008), salienta que os trabalhos de demarcações dos lotes em Paiol Grande, primeiro nome para Erechim, iniciaram por volta de 1900, e que chegaram imigrantes; russos, ucranianos, lituanos, poloneses, prussianos, espanhóis, holandeses, portugueses e austríacos à região, de maneira espontânea ou através de companhias de imigração. A empresa colonizadora Luce Rosa Cia Ltda, que era uma empresa privada com sede social em Porto Alegre, que trazia os imigrantes alemães e italianos e responsável por quatro povoações; Três Arroios, Nova Itália, (Severiano de Almeida), Dourado e Rio Novo, região do município de Aratiba, conforme Cese (1979). Outra iniciativa foi empresa inglesa, de cunho privado-filantrópico, Jewish Colonization Association, que comprou a maior extensão de terras devolutas do governo e fundou a colônia Quatro Irmãos, e Erebango. Os imigrantes vinham por meio do transporte ferroviário ${ }^{10}$, que ligava São Paulo ao Rio Grande do Sul. Também, muitas "famílias de afrodescendentes provenientes de outras cidades do estado e do país começaram a se fixar, $[\ldots]$ eram de ferroviários e operários que trabalharam na construção do ramal férreo", segundo Tedesco (2017: 151).

\footnotetext{
5 Os primeiros habitantes do Planalto Sul Rio-Grandense são os índios; Tapes, Guaranis, e jês, "Os caingangues $(k a a=$ mato + ingáng $=$ morador $=$ habitante do mato são os descendentes do grupo Jês. Eles habitavam as áreas do Planalto- Médio e Norte rio-grandense" (CHIAPARINI, 2012: 12).

${ }^{6}$ Era o nome dado aos descendentes dos bandeirantes e tropeiros paulistas que colonizaram a região serrana.

${ }^{7}$ Guerra dos Farrapos ou Revolução Farroupilha (1835-1845), revolução ou guerra regional de caráter republicano, contra o governo imperial do Brasil, na então província de São Pedro do Rio Grande do Sul, e que resultou na declaração de independência da província como estado republicano, dando origem à República Rio-Grandense.

${ }^{8}$ Foi uma guerra civil na região Sul do Brasil, (1893-1895), o conflito originou-se da crise política gerada pelos federalistas, grupo opositor que pretendia libertar o Rio Grande do Sul da governança de Júlio de Castilhos, então presidente do estado, conquistar maior autonomia e descentralizar o poder da então recém proclamada República.

${ }^{9}$ É o mestiço de branco com índio. O tupinólogo Eduardo de Almeida Navarro defende que "caboclo" se originou do termo tupi kuriboka, que, num primeiro momento, designava o filho de índio com africana. Mais tarde, kuriboka teria passado a se referir também ao filho de mãe índia e pai branco e depois ao mestiço de caboclos e brancos.

${ }^{10}$ A estrada de ferro São Paulo- Rio Grande (EFSPRG) teve 12 estações ferroviárias entre Passo Fundo e Marcelino Ramos na barranca do rio Uruguai/ Pelotas. Foram elas: Coxilha, Sertão, Estação Erechim (atual município de Estação), Erebango, Capo-Erê (atual município de Erechim), Balisa (foi demolida para a construção da estação Barro), Marcelino Ramos, a Estação Experimental de Trigo de Passo Fundo (atual distrito Englert, pertencente a Sertão), além da própria estação de Passo Fundo, conforme (TEDESCO, 2017: 182
} 
Segundo Silva (2020: 38), no início do século XX o incentivo para a imigração no Brasil tinha caráter racista, porque "as políticas de branqueamento, do elogio à mestiçagem, juntamente com a tese mítica da democracia racial se configuraram, no tempo, como estratégias de manutenção do poder e de privilégios para sujeitos brancos". Em Rio Grande do Sul: Aspectos da Negritude, Vera Triumpho (1991: 113), salienta que o imigrante tinha facilidades na aquisição de terras ou era facilmente inserido no mercado de trabalho nas lavouras, enquanto que o negro teve: “[...] a transição do trabalho escravo para o livre, em verdade, uma concorrência desleal. O negro integra um mercado de trabalho livre, onde a mão-de-obra qualificada era o imigrante". O povo negro muito contribuiu para o desenvolvimento do país, entretanto, foi o primeiro a ficar sem-terra. Com a abolição o negro ficou sem terra e sem trabalho" (TRIUMPHO, 1991: 18).

Tedesco (2017) salienta que com a imigração na região do Planalto Médio, no final do século XIX e início do século XX, “o processo de expropriação do indígena e caboclo, principalmente pelas políticas colonizadoras e pela força do latifundiário pastoril, intensificou-se" (TEDESCO, 2017: 118). Na publicação do Biênio da Colonização e Imigração, O negro e descendentes na sociedade do Rio Grande do Sul (1635-1975), de autoria de Cláudio Moreira Bento, e enfatizado que:

O Negro não foi imigrante nem colono. Mas foi peão de estância, foi domador, foi cavaleiro, foi soldado, foi revolucionário, foi braço anônimo que carregou pedra na construção ciclópica dos molhes de Rio Grande e braço que bateu pino, arduamente, na construção das linhas férreas que cortaram o território do continente. Foi mineiro a céu aberto e deu carvão para que a indústria nascesse no Sul. Foi mateiro, valente e destemido, que abriu os caminhos do Alto Uruguai [...] (BENTO, 1976: 16).

$\mathrm{O}$ indígena e $\mathrm{o}$ afrodescendente tiveram papel fundamental para $\mathrm{o}$ desenvolvimento regional, embora sejam alguns grupos de origem europeia os enaltecidos - talvez também como reflexo da quanto a quantidade de pesquisas no ramo acadêmico. É necessário trazer para historiografia a participação mais efetiva desses grupos e dos afrodescendentes no desenvolvimento cultural e econômico, dirimindo esse silenciamento histórico. O termo negro, para esta pesquisa, é "sinônima da expressão africano-brasileiro, que melhor corresponde aos objetivos de resgate da história, cultura, 
religião, visão de mundo, dos descendentes dos africanos escravizados no Brasil", conforme a definição de Triumpho (1991: 13).

A trama em Cogumelos de Outono se passa na cidade imaginária Boa Vista, no Vale do Rio Dourado. O tempo da narrativa transcorre de 1923 a 1945, e traz a representação das relações interétnicas entre dos afrodescendentes e dos imigrantes estabelecidos em Erechim. O primeiro personagem para análise da narrativa é o coveiro Maroca,

[...] - Engraçado? É somente isso que sabe dizer para justificar a sua incompetenza? Madonna mia! - Exclamou o Major como se declamasse uma citação inédita, - Ainda que mal pergunte, zelatore, - prosseguiu irônico e uma espécie de alegro moderato - onde é que o senhor andava quando foi realizado esse maldito acompanhamento? - Andava capinando por aí, doutor . . . respondeu Maroca, muito calmo. - Per favore, não me chame de Dottore atalhou o Major como se fosse picado por uma cobra. -«Major», já lhe disse! - Advertiu, em voz alta, forte. - Quantas vezes precisarei repetir-lhe que servi a pátria com uma farda e não com um aventale? - Desculpe, Major - retrucou Maroca com humildade - mas o senhor é tão legal que a gente às vezes fica meio contundido ..., - Legale? Dio santo, que significa isso? Maroca esforçou-se para explicar: - Hum... é uma pessoa fina, asseada, enxuta. . .Piacere - agradeceu o Major com aquela modéstia dos nobres quando recebem uma comenda que já fazia parte do montepio sanguíneo. Fez uma pequena pausa para gozar o elogio. Questa giria brasiliana generalmente mi confonde.... Deu alguns passos solenes por volta da sepultura, depôs os braços nas costas e prosseguiu: - Quer dizer que, em resumo, o senhor não viu nada mesmo. Niente, vero? - Minha catarata não me deixa, Major. - Maroca apontou para os olhos marrons, sem brilho [...] (MÁRSICO, 1972: 14).

Neste trecho, Gladstone traz a representação do trabalhador Maroca, conversando com o imigrante ítalo Giovanni Pandolfo, nota-se que há uma diferença linguística entre ambos, Giovane dialoga em língua italiana. Segundo Helena Confortin (1998), em sua obra, A faina linguística: estudos de comunidades bilíngues italiano-português do Alto Uruguai Gaúcho, traz que falar italiano para o imigrante era praticado pelos (adultos ou os filhos deles), era natural a comunicação, o português era língua de comunicação para 
com a outra cultura, ou seja, mesmo estando em território brasileiro, continuavam a falar seu idioma de origem.

O personagem Maroca ocupa espaço de zelador de cemitério, enquanto o imigrante recém-chegado Giovanni é o prefeito de Boa Vista, quem fiscaliza o serviço de Maroca. Triumpho (1991) salienta que o negro não ocupa o cargo de administrador devido a questão ideológica do branqueamento da classe dominante,

[...] são valores e ideias da classe dominante branca, materializada em prática social, procurando coibir o espaço do negro na gerência da sociedade. $\mathrm{O}$ branco apresentar-se-á naturalmente senhor, justificando sua função de mando e de administrador. O negro deve trabalhar, gerar excedente, não usufruir totalmente da produção e transferir maior parte do fruto aos demais grupos (TRIUMPHO, 1991: 138).

Na mesma linha, Mario Maestri (2008: 71), salienta que no Sul: “os “dominantes" não necessitavam "tiranizar os dominados", pois a "sua superioridade era natural, harmoniosa em tudo". Nota-se que Maroca trata Giovane com certo respeito, chamandoo de doutor ${ }^{11}$, que historicamente foi um erro disseminado, devido a forma de se dirigir as pessoas que tivessem a formação acadêmica. Porém, na trama Maroca é corrigido para chamar o imigrante de Major, porque para este lhe dá ainda maior satisfação, visto que participou numa revolução e quer méritos por isso. Posteriormente, Mársico satiriza o título de Major, visto que não é por merecimento. Maroca diz que o Major é legal, e o Major quer saber o que significa o termo legal, pois não entende todas as palavras e gírias do vocabulário de Maroca, isto quer nos mostrar - em termos ampliados, que aprender língua portuguesa era vital ao imigrante. Situação análoga aparece em Memórias de Quatro Irmãos, Samuel Chwartzmann, sobre a ajuda dos nativos, afirma: "Os imigrantes judeus foram recebidos por aqueles caboclos de braços abertos. A maioria deles era analfabeta, mas honesta e leal. Ensinaram aos judeus o português, que foi de muita utilidade, principalmente para os que foram para as cidades, pois conseguiram, a partir daí se comunicar com seus clientes" (CHWARTZMANN, 2005: 44).

\footnotetext{
${ }^{11} \mathrm{O}$ termo "Doutor", é um título acadêmico de quem terminou o $3^{\circ}$ ciclo do ensino superior e não um pronome de tratamento.
} 
Conforme Triumpho (1991: 179), “[...] o colonizado que se deixa assimilar é aparentemente aceito pelo colonizador. As relações entre eles são cordiais ou até mesmo solidárias, na medida em que se aceita os gestos de proteção e caridade desse, e retribui com fidelidade e admiração [...]". Em Cogumelos de Outono, sobre as características físicas do coveiro Maroca:

O zelador era, sem dúvida, uma criatura pitoresca que mereceria por necrológio a imortalidade duma Tela. O cabelo encarapinhado e branco como se fossem as rugas dum cômoro de areia, a cor retinta da pele, o bigode recheado e caído sobre a comissura labial semelhante às nádegas dum ouriço, e um olhar condescendente de quem já pintou o sete no passado, mas, agora, nem mais se entusiasma com o cheiro da tinta, moldava-lhe o pedigree daqueles escravos muito espertos dos navios negreiros que, ao invés de preferirem a comodidade dos porões, acharam mais prático bancar logo o mordomo do capitão. Assim, na pior das hipóteses, o ar que respiravam era menos condicionado (MÁRSICO, 1972: 16).

Aqui, Mársico, traz um homem sofrido pela idade e pelo trabalho árduo, com cabelo encarapinhado e o assemelha com os afrodescendentes que foram escravizados ainda em África e mantiveram esse status por séculos no Brasil. Segundo Triumpho (1991: 18): “[...] o negro está há cinco séculos no Brasil. Há cinco séculos que ele tem sido força motora de acumulação capitalista, sempre localizado nos piores setores da economia e vivendo, na maioria, em condições desumanas. Historicamente, o negro passou dos porões dos navios negreiros para os porões da sociedade brasileira".

O significado do nome Maroca, é associado ao "fofoqueiro" que é o nome dado para pessoa que gosta de levar notícias em sua cidade do interior para todos os munícipes, essa característica associa-se ao zelador do cemitério, porque na ficção ele costuma informar os acontecimentos do cemitério para Giovanne Pandolfo, e num outro trecho da obra, ele é quem avisa o delegado sobre o caso do cachorro Epaminondas enterrado no cemitério. Já, a segunda personagem negra é Maroca dos Prazeres, que possui o mesmo nome da primeira personagem, e o acréscimo do sobrenome "dos Prazeres", carrega uma noção de aprazimento.

Em Cogumelos de Outono, em 1923, ocorre a Revolução Federalista no estado e no Vale do Rio Dourado, havendo diversas escaramuças na localidade de Quatro Irmãos. 
O tropeiro maragato Maroca dos Prazeres, vem de Lagoa Vermelha para Boa Vista trazer uns gados para uns fazendeiros de Quatro Irmãos, e nesta viagem resolve ir à missa usando lenço vermelho. Então, Frei Ventura chimango resolve falar em política na missa, e Maroca descorda dos apontamentos dele. Então, Maroca é expulso e agredido verbalmente, para intimidar o frei, Maroca dá um tiro com uma arma que não continha balas, somente pólvora assustando todos os fiéis presentes na missa. Frei Ventura não se ferre e diz várias vezes inesperadamente, para um outro frei é "mea culpa". A população em sua maioria católica apoia o Frei Ventura, desmerecendo Maroca por ser negro e maragato. Depois disso, Maroca se esconde, e o delegado e o cabo têm medo de fantasmas, por isso não entram no Matinho da Comissão para procurar Maroca. Durante a noite, Maroca se entrega na delegacia e pede para ficar preso, pois tem medo de ser linchado. Depois disso, Boa Vista organiza o júri num clube mesmo sem estrutura com muitos atrapalhos conseguem um advogado que aceita a causa, e o juiz da comarca de Passo Fundo é responsável pelo julgamento,

[...] a situação de Maroca dos Prazeres, o réu, não era nada boa. Tirando os veneráveis irmãos da Loja Maçônica de Passo Fundo, que deram uma gozada secreta quando souberam da notícia e alguns ardorosos, fanáticos e anônimos simpatizantes de Assis Brasil - a asa negra do castilhismo - todo o resto da população tomara partido do padre. Era só o que faltava: um negro e, ainda por cima, maragato, ter o topete de atirar num Ministro de Deus dentro duma Igreja e em pleno sermão! Onde e que iriam parar? (MÁRSICO, 1972: 150$151)$.

Nota-se que o motivo inicial da briga com o frei foi a oposição partidária de Maroca dos Prazeres em ser maragato ${ }^{12}$, ou seja, um envolvimento político contrário a postura do religioso. A Revolução Federalista, segundo Abreu (2021, p. 1), foi uma

Guerra civil entre federalistas partidários de Gaspar Silveira Martins, os chamados "maragatos", e republicanos partidários de Júlio de Castilhos, os "pica-paus", que conflagrou o Rio Grande do Sul, Santa Catarina e Paraná entre fevereiro de 1893 e agosto de 1895 . O conflito envolveu amplas forças

\footnotetext{
${ }^{12}$ Adepto do movimento federalista que, em 1893, inspirou a revolução sob chefia de Silveira Martins contra o partido então dominante, que tinha à frente Júlio de Castilhos.
} 
militares locais e ainda remanescentes da Revolta da Armada, aliados dos federalistas, e se encerrou com a vitória dos republicanos.

Mársico transpôs para a ficção, o período de revoluções no Rio Grande do Sul, a Revolução Federalista e a Revolução de 1923. Segundo Lando (1996: 84), em 1923 ocorreu o movimento revolucionário que atingiu a vila Quatro Irmãos [ ex distrito Erechim], que sofreu em suas terras "um combate travado entre as facções rivais brasileiras, sendo alvo de várias pilhagens". Sabe-se que a entidade Igreja Católica na década de 30, ocupava posição superior frente as decisões tomadas na colônia, por isso teria a maioria da população católica a seu lado, exceto a população representada pelos maçônicos ${ }^{13}$. No trecho, "era só o que faltava: um negro, e ainda por cima maragato, ter o topete", Mársico traz o modo de pensar de uma população racista e a estigmatização ${ }^{14}$ do afrodescendente. Segundo Triumpho (1991: 140), “o branqueamento da sociedade sulina cria nexo com a superioridade do branco, universalizando tal ideologia, filtrando e governando o comportamento dos grupos, onde a inferioridade do negro transforma-se em 'senso comum"”.

Em Cogumelos de Outono, "O mais grave de tudo era que Maroca não passava de um forasteiro, residia noutras bandas. Viera de Lagoa Vermelha para trazer um gado a dois fazendeiros, de Quatro Irmãos, chegara numa sexta, fizera as contas no sábado e, domingo, antes de viajar, resolvera ir à Missa".

Neste trecho, Gladstone o descreve como um tropeiro, porque indica a um homem que anda a cavalo, meio de transporte da época, conduzindo gado aos fazendeiros. Maroca dos Prazeres realiza as ligações comerciais através do tropeirismo ${ }^{15}$. A ficção descreve a travessia de um tropeiro que utilizava uma estrada específica que

[...] levava em direção ao distrito de Passo Fundo, Lagoa Vermelha e Vacaria, tendo ramais ao norte, para o distrito de Palmeira, Nonoai e Campo Novo, que se interligavam com as províncias de Santa Catarina e Paraná. Essa estrada,

\footnotetext{
${ }^{13}$ Existiam duas lojas Maçônicas em Erechim, uma delas era a Loja Aknaton, fundada em 25 nov.1972, e a outra Loja José Bonifácio, fundada na década de 40, conforme Ducatti (1981).

${ }^{14}$ Há estudos de Mariana Amaro Theodoro de Almeida sobre o estigma racial e o tratamento jurídico penal do negro no Brasil.

${ }^{15}$ Fenômeno conhecido desde o período colonial, grande movimento histórico e social fundamental para o desenvolvimento comercial que interligou diferentes e longínquas áreas da colônia e sobreviveu até o século XX.
} 
que seguia o sentido norte, atalhava enormemente o caminho das tropas de gado e de sua abertura concluída em 1846 (ARAÚJO, 2008: 34).

Já em Memórias de Quatro Irmãos, de Samuel Chwartzmann, sobre o trabalho afrodescendente, afirma: “[...] Dispuseram-se a auxiliar nas "lidas campeiras", como domar potros para montar, amansar bois para os serviços nas lavouras, tirar leite de vacas, fabricar queijos, tratar animais doentes e tantos outros" (CHWARTZMANN, 2005: 4445). Além disso, em Cogumelos de Outono, Maroca dos Prazeres é um:

Bom católico, supersticioso, não perdia aquela cerimônia por nada deste mundo, especialmente em Igreja nova, ainda não visitada, para ter a chance daquelas três graças prometidas. Pusera o lenço vermelho no pescoço porque, sem ele, era como se não tivesse nada por baixo. Desde que o recebera de presente do General Santo Cristo Rezende - o grande chefe revolucionário, infelizmente derrotado pelo Capitão Gaudério, com reforço estrangeiro - e se tornara maragato, fizera dele uma relíquia, não o tirava do corpo nem para dormir. Cometera uma besteira - reconhecia - em apartear o padre na Igreja. Mas não resistira. Chamar aquele seu escapulário de comunista, era forte. . . Estava um pouco arrependido, desrespeitara a Casa de Deus, era verdade, mas se consolava com a lembrança de que Jesus Cristo também usara uma arma na Igreja, só que fora um laço porque naquele tempo ainda não se descobrira a pólvora. Nunca dera um tiro em ninguém, era o assador da coluna, homem pacifico e de bom tempero, que usava o revólver apenas para impor respeito (MÁRSICO 1972: 151).

Maroca usa um lenço vermelho no pescoço, isto faz rememorar a atuação da liderança afrodescendente na Revolução Federalista como é o caso do tenente-coronel Adão Latorre ${ }^{16}$. Maroca se arrepende por ter desrespeitado a casa de Deus, mas não por ter defendido sua honra. Conforme a ficção, suas atitudes eram pacíficas e de bom temperamento, ele usava o revólver contendo somente pólvora, sem balas, apenas para impor respeito. Em Cogumelos de Outono,

${ }^{16} \mathrm{O}$ tenente-coronel Adão Latorre foi um militar revolucionário maragato que lutou na Revolução Federalista. Adão ficou famoso pela bravura mostrada em batalha e pelo amplo emprego da degola dos prisioneiros inimigos. 
A verdade, porém, era que Maroca estava praticamente só e fora uma luta até para conseguir lhe advogado. A comarca de Boa Vista ainda não fora sequer instalada e tinha como sede a jurisdição de Passo Fundo. De lá vinha o Juiz fazer as audiências, que eram vigiadas pela curiosidade popular, e onde o Maroca não metia a cara sem receber vaia. Ele chegava escoltado desde os porões da Intendência, por uma guarda especial (fazia parte da comitiva do Meritíssimo para garantir a ordem dos trabalhos), passando pela rua como se fosse para o matadouro e cada vez que entrava no Fórum - um pardieiro, caindo aos pedaços, na rua do cemitério - havia gente na calçada par a saudálo. Até uma pedrada recebera certa ocasião, na cabeça e quando mostrou o galo ao sargento, reclamando, teve a resposta de que era melhor aquilo nos miolos do que a corda no pescoço - devia acender uma vela! (MÁRSICO, 1972: 151).

Mársico traz a representação da dificuldade de ser realizado um júri e de como foi difícil conseguirem um advogado de defesa para Maroca dos Prazeres, por isso realizaram seu julgamento num clube da cidade, e não no Fórum, pois este não existia, o que coincide com a data de inauguração do Fórum de Erechim, cidade inspiradora da ficção, foi 11 de agosto de 1954, posterior a data do julgamento na ficção. Também, é verossímil a localização da delegacia nos porões da Prefeitura de Erechim ou Intendência. Na ficção "havia gente na calçada par a saudá-lo. Até uma pedrada recebera certa ocasião, na cabeça", enquanto aguardava o julgamento, sofreu discriminação social e racismo por parte da população. Segundo Giralda Seyferth, “[...] O racismo brasileiro, portanto, tem muitas representações destacando-se a teoria do branqueamento da raça, doutrina construída nos meios científicos e intelectuais do início do período republicano que tinha como parâmetro as várias ideias sobre determinismo social e ambiental" (SEYFERTH, 2016: 331).

Complementando, o racismo é “a combinação de um preconceito negativo, baseado na cor da pele de uma pessoa, com o poder formal e informal de impedir a pessoa de alcançar seus objetivos e direitos na vida”, conforme Nash (2000: 77). Dessa forma, o linchamento na ficção, foi a representação de um ato racista.

Em Cogumelos de Outono, o autor deixa bem claro ao leitor que Maroca dos Prazeres é inocente, 
Frei Ventura, por exemplo, não morrera do tiro. Quando pressentiu que ia ser atingido, quis se agachar no púlpito, fazendo-o de escudo, mas, na pressa, bateu violentamente com as costas na quina da platibanda traseira e caiu meio tonto. Ficou ali alguns segundos, enredado no madeirame, até que Frei Bento e Frei Cândido alertados pelo estampido, gritos e correrias, vieram socorrêlos a sacristia aos berros de «mea culpa, mea culpa! » Quando Frei Ventura abriu os olhos apalpou-se inteiro à procura do ferimento, que supunha mortal, pensando na bala. Mas, ao constatar que não era nada - mais o susto! - Deu graças a Deus por estar vivo, e quis, ao menos uma justificativa do tombo, para manter as aparências, gemendo, enquanto se aprumava: - << estou ferido, estou ferido... >> (MÁRSICO, 1972: 143).

Gladstone, ao se posicionar defender Maroca, parece dizer na voz da personagem padre que esse fora culpado, o que se sobressai com a frase "mea culpa!". Parece que Mársico quer deixar a personagem falar o seu ponto de vista, de autor. Em Cogumelos de Outono o juiz questiona Maroca dos Prazeres acerca do ocorrido,

[...] - Por que é que o senhor atirou no padre? - Porque me chamou de preto respondeu Maroca, prontamente. O Barba Negra fez nova careta: - E o senhor acha que é branco? Ouviu-se um sussurro de aprovação no auditório ... O Barba Negra, para manter a imparcialidade, ameaçou de bater na campainha, mas não foi preciso. O recolhimento foi imediato. Maroca nada respondeu., abaixou a cabeça., silenciosamente. O Barba Negra prosseguiu no interrogatório: - O senhor queria matar o Padre? - Não senhor. - Por que atirou, então? - Foi só de penitência, seu Doutor. [...] Agora foi O Barba Negra que pareceu levar um susto com a resposta de Maroca dos Prazeres. Mas reprimiu a careta, para não se achado, e perguntou com certa ironia: _. Quer dizer que, quando o chamam e preto, o senhor costuma fazer dessas penitências - Não, Como? Doutor. Foi a primeira vez - defendeu-se Maroca. Como? Nunca o chamaram de preto, antes? -- Dentro duma Igreja, não, seu Doutor. O Barba Negra engoliu a resposta com discrição para não dar na vista. $\mathrm{O}$ acusado não era lá tão burro como parecia ... - E por que foi que aparteou o Padre? - Insistiu, penem apertá-lo. Por causa disto aqui - respondeu Maroca, exibindo o lenço vermelho do pescoço (MÁRSICO, 1972: 1957-158). 
Mársico traz o julgamento de Maroca, o uso do termo "preto" carregou sentido pejorativo, visto que o padre, e até mesmo o juiz, demonstram uma concepção racista nos diálogos. Há também outro trecho em que Maroca sente-se ofendido: “[...]- Estão com medo deste negro? - Instigou Frei Ventura, lá do púlpito, quando viu toda a família Rampanella agachada nos bancos [...]. Maroca não aguentou a injúria. Levantou o cano do revólver com muita calma, fez pontaria e deu um tiro no padre" (MÁRSICO, 1972: 141).

O trecho, "Estão com medo deste negro", coloca o Maroca numa posição de inferioridade novamente, visto que se sente ofendido pelo padre, que a injúria em público. O motivo do tiroteio foi o desrespeito a honra de Maroca dos Prazeres. Maroca, na posição de réu, deveria acusar o frei Ventura das calúnias e injúrias sofridas, por isso, Mársico termina sua narrativa ficcional absolvendo o tropeiro Maroca das acusações.

A obra de Gladstone Osório Mársico tem como característica a transposição verossimilhante do espaço, personagens e período histórico em que sua literatura foi criada. De acordo com Ferreira (2010: 2): “[...] o verossímil não é mais, portanto, que uma analogia do verdadeiro, e por isso pode-se dizer que a ficção é a capacidade de um fazer crer, mercê do qual o artifício é tomado como um testemunho autêntico sobre a realidade e a vida. Ou seja, a arte da ficção manifesta-se como arte da ilusão".

Faz-se importante trazer a reportagem do dia 29 de janeiro de 1945, publicada no jornal local, A Voz da Serra, devido a coincidência nos fatos entre a reportagem e as características do segundo personagem Maroca dos Prazeres. A reportagem intitulada Absolvido Miguel do Amaral descreve o que segue:

O Supremo Tribunal de Apelação do Estado acaba de confirmar por unamidade de votos a resolução do Tribunal do Erechim que absolveu o denunciado Miguel do Amaral, que em 1930 numa festa religiosa, em Rio Toldo, tombou a tiros de revólver dois seus adversários políticos e feriu um outro. O motivo foi estar Miguel do Amaral com um lenço vermelho no pescoço e ser "maragato". As vítimas eram "chimangos". Praticado o crime, Miguel do Amaral fugiu para o município de Palmas, no Estado do Paraná, onde veio cometer novo crime de morte, visto ter sido assaltada a sua residência por três facínoras, tendo matado o chefe da "trinca", conhecido pela alcunha de "Castelhano". Preso respondeu processo pela Justiça Paranaense, tendo o Tribunal do Júri absolvido, cuja sentença foi reformada pelo Tribunal de Apelação do Paraná que o condenou a 15 anos de prisão visto ter a 
Promotoria Pública feito prova do processo que havia sido instaurado pela Justiça de Erechim. A requisição da justiça local, Miguel do Amaral será remetido para Erechim. A Promotoria Pública do Erechim em seu libelo acusatório pedia a condenação de Miguel do Amaral a 41 anos de prisão. A defesa de Miguel do Amaral esteve aos cuidados do Dr. Octacilio M. da Costa, que conseguiu a absolvição do Tribunal do Júri sob alegação de que Miguel do Amaral agiu em legítima defesa própria. A Promotoria Pública de Erechim não se conformando apelou para o Supremo Tribunal de Apelação do Estado, que confirmou por maioria absoluta de votos a sentença do Tribunal de Júri que reconheceu ter agido Miguel do Amaral em legítima defesa de sua própria pessoa (A VOZ DA SERRA, 1945: s/p).

Aqui, o evento ocorre a verossimilhança, com o evento histórico ocorrido com Miguel do Amaral e o personagem Maroca dos Prazeres da ficção. Ambos se envolvem num tiroteio devido sua posição partidária e são julgados. Existe a hipótese, que Mársico tivesse assistido este julgamento em Erechim, porque na época foi muito comentado pelos munícipes, e ele na época teria 18 anos de idade, frequentador do Curso de Ciências Jurídicas. Observando tais coincidências, e muitas outras evidentes na sua obra, pode-se referendar a perspectiva de Triumpho (1991: 46), “[...] a narrativa é o reflexo da sociedade em que vivemos e nesta medida, reafirmamos, seu discurso está compatível com os estereótipos por ela reproduzimos".

\section{Considerações finais}

O artigo visou analisar Cogumelos de Outono, produzida por Mársico, na qual continha a representação afrodescendente, ora trabalhando como zelador cemiterial, ora no tropeirismo. Pode-se concluir que os trechos analisados carregam em si representações da participação cultural e social do afrodescendente na cidade de Erechim, visto que o autor traz o modo de pensar de uma população racista que estigmatiza o afrodescendente.

A historiografia oficial tem uma dívida para com o afrodescendente, uma vez que há dificuldade em encontrar materiais que tratem das contribuições socioeconômicas culturais dos afrodescendentes no contexto Norte do Rio Grande do Sul, especialmente em Erechim. Espera-se que esse artigo, através da análise literária, possa instigar uma nova fonte para compreensão das contribuições dos afrodescendentes na história local. 


\section{Referências bibliográficas}

ABREU, Alzira Alves (s.d). Revolução Federalista. Disponível em: < https://cpdoc.fgv.br/sites/default/files/verbetes/primeirarepublica/REVOLU\%C3\%87\%C3\%830\%20FEDERALISTA.pdf >. Acesso em: 05 fev. 2021.

ARAÚJO, Tiago Leitão (2008). Escravidão, fronteira e liberdade: políticas de domínio, trabalho e luta em um contexto produtivo agropecuário (Vila de Cruz Alta província do Rio Grande de São Pedro, 1834-1884). Disponível em: < https://www.lume.ufrgs.br/bitstream/handle/10183/17528/000716785.pdf?sequen ce $=1>$. Acesso em: 29 jan.2021.

A VOZ DA SERRA (29 de janeiro de 1945). Absolvido Miguel do Amaral. Erechim: Arquivo Histórico Juarez Miguel Illa Font.

BALDISSERA, Marli de Almeida (2008). De Campo pequeno ao grande Erechim. Erechim: Edifapes.

BENTO, Cláudio Moreira (1976). O negro e descendentes na sociedade do Rio Grande do Sul (1635-1975). Porto Alegre: Grafosul, Instituto Estadual do livro.

CESE. Centro de Ensino Superior de Erexim (1979). Histórico de Erechim. Passo Fundo: Instituto Social Padre Berthier.

CHARTIER, Roger (1988). A história cultural: entre práticas e representações. Rio de Janeiro: Bertrand Brasil.

CHIAPARINI, Enori José (2012). Erechim: Retratos do passado, memórias do presente. Erechim: Graffoluz.

CHWARTZMANN, Samuel (2005). Memórias de Quatro Irmãos. Porto Alegre: Est Edições.

CONFORTIN, Helena (1998). A faina linguística: Estudo de comunidades bilíngues italiano-português do Alto-Uruguai Gaúcho. Porto Alegre: Edições EST/ URICampus de Erechim.

DUCATTI, Neto, Antônio (1981). O grande Erechim e sua história. Porto Alegre: Escola Superior de Teologia.

FERREIRA, Antonio Sérgio (2010). Relações entre Literatura X História. Diálogos Acadêmicos. Revista Eletrônica da faculdade Semar/Unicastelo. Disponível: <http://uniesp.edu.br/sites/_biblioteca/revistas/ 20170627110749.pdf >. Acesso: 2 fev. 2019.

GARCEZ. Neusa Cidade (2008). Marcos do colonizador: o "Castelinho" e a Casa. Erechim, RS: Edifapes.

GONZÁLEZ, Mário (1988). O romance picaresco. São Paulo: Ática.

JORNAL A VOZ DA SERRA (29 jan.1945). Absolvido Miguel do Amaral.

LANDO, Aldair Marli (1996). RS: imigração \& colonização. Porto Alegre: Mercado Aberto.

LINHARES, Temístocles (1987). História Crítica do Romance Brasileiro. Rio de Janeiro: Itatiaia.

MAESTRI, Mario (2008). História e historiografia do trabalhador escravizado no RS: 1819-2006. Disponível em: < http://bibliotecavirtual.clacso.org.ar/clacso/coediciones/20100823031132/06mae.p $\underline{\mathrm{df}}>$. Acesso em: 28 jan. 2020.

MÁRSICO, Gladstone Osório (1972). Cogumelos de Outono. Porto Alegre: Editora Movimento.

NASH, Peter (2000). Algumas reflexões sobre o negro em espaços hegemônicos da sociedade brasileira. São Leopoldo: Mimeo, 
PESAVENTO, Sandra Jatahy (2003). O mundo como texto: leituras da História e da Literatura. Revista: História da Educação ASPHE/FaE/UFPel, Pelotas, n.14, p. 3145.

REVISTA VEJA (edição $n^{\circ}$ 187, de 5 de abril de 1972, p. 88). Sessão de Literatura. $\grave{A}$ espera do Führer.

SANTOS, Renato Emerson (2009). Diversidade, espaço e relações étnico-raciais: $O$ Negro na Geografia do Brasil. Belo Horizonte: Editora Gutenberg, (Coleção Cultura Negra e Identidades).

SEYFERTH, Giralda (2016). Estudos sobre a imigração alemã no Brasil. Rio de Janeiro: Contracapa.

SEYFERTH, Giralda (2002). Racismo no Brasil. São Paulo: Peirópolis; ABONG. Vários autores.

SILVA, Karine de Souza (2020). "A MÃO QUE AFAGA É A MESMA QUE APEDREJA": DIREITO, IMIGRAÇÃO E A PERPETUAÇÃO DO RACISMO ESTRUTURAL NO BRASIL. Revista Mbote, Salvador, Bahia, v. 1, n.1, p.020041. Disponível em: < https://www.revistas.uneb.br/index.php/mbote/index >. Acesso em: 30 jan.2021.

SOETHE, Paulo Astor (1998). Sobre a sátira: Contribuições da teoria literária alemã na década de 60. Revista Fragmentos, Florianópolis, v.7 n.2. Disponível em: < https://periodicos.ufsc.br/index.php/fragmentos/article/viewFile/6014/5559 >. Acesso: 24 jan. 2019.

TEDESCO, João Carlos (2017). Conflitos agrários no norte do Rio Grande do Sul: indígenas e agricultores- dimensões históricas. Porto Alegre: EST Edições.

TEDESCO, João Carlos (2017). A formação étnica de Passo Fundo: história, memória e patrimônio. Erechim: AllPrint Varella.

TRIUMPHO, Vera Regina Santos (1991). Rio Grande do Sul: Aspectos da Negritude. Porto Alegre: Martins Livreiro.

Artigo recebido em 08 de fevereiro de 2021.

Aprovado em 01 de junho de 2021.

DOI: 10.12957/intellectus.2021.57642 